\title{
Donyi-Polo and Deep Ecology: A Select Reading of Mamang Dai's Midsummer Survival Lyrics
}

\author{
Sukla Singha \\ Research Scholar, Department of English, Tripura University, Tripura, India, ORCID ID: \\ oooo-0oo3-4948-7297, Email: shukla.singha85@gmail.com
}

\begin{abstract}
The Adis of Arunachal Pradesh consider everything coming from nature as sacred and living. As opposed to the Christian theological teachings that regard humans as the conqueror of everything else on earth, in the Adi worldview, human beings do not occupy the center stage. Instead, the Adis believe in the intrinsic worth of all beings - both human and nonhuman, which exist on earth, as reflected in the Adi philosophy of 'Donyi-Polo.'This paper attempts to study select poems from Mamang Dai's book of poems Midsummer Survival Lyrics (2014) in the light of the philosophy of Donyi Polo. It also attempts to link this Adi worldview to the ecosophy of Arne Naess popularly known as 'Deep Ecology.'
\end{abstract}

Keywords: Donyi-Polo, Deep Ecology, Ecosophy, Human, Nonhuman

\section{Introduction}

The phrase "Deep Ecology Movement" was coined by the Norwegian philosopher Arne Naess in 1972 to distinguish it from the "Shallow Ecology Movement."The Shallow Ecology Movement, was simply a "fight against pollution and resource depletion" (Naess 1995, 151) started by humans in developed countries for their own survival, without considering the survival of nature and its elements. On the other hand, supporters of the Deep Ecology Movement take a broader view and "look for long-term solutions, engage in deep questioning, and pursue alternative patterns of action" (Naess 2008, p. 26). In other words, while the Shallow Ecology Movement focusses on the welfare of humans on earth, the Deep Ecology movement believes in the worth of all beings on earth. To make his approach clear, Naess (2008) had propagated an ecosophy of "living in an ecologically responsible way in harmony with nature" (p. viii). The word 'ecosophy' is made up of oikos meaning 'household' and sophia meaning 'wisdom.' Ecosophy, for Naess, is ecological wisdom: "By an ecosophy I mean a philosophy of ecological harmony or equilibrium" (Naess 20o8, p. 32). In that sense, ecosophy becomes a worldview or value system inspired by the conditions of life in ecosphere.Hinting upon this notion of living in an ecologically harmonious way on planet earth, Cheryll Glotfelty (1996) writes on how ecocriticism as an approach to studying literature "expands the notion of 'the world' to include the entire ecosphere" (Glotfelty 1996, p. xix).

The platform principles of Deep Ecology Movement were first outlined in 1984 by Naess and have undergone several revisions since. The 1993 version (Guha 2004, p. 116-117) includes the following points:

(c) AesthetixMS 2020. This Open Access article is published under a Creative Commons Attribution Non-Commercial 4.o International License (http://creativecommons.org/licenses/by-nc/4.o/), which permits non-commercial re-use, distribution, and reproduction in any medium, provided the original work is properly cited. For citation use the DOI. For commercial re-use, please contact editor@rupkatha.com. 
1. The worth of nonhuman beings is independent of their usefulness for humans.

2. All life-forms on earth have intrinsic worth.

3. Humans have no right to reduce this richness and diversity, except to satisfy vital needs.

4. The flourishing of human life and cultures is compatible with a substantially smaller human population.

5. Human interference with the nonhuman world is excessive, and the situation is worsening.

6. Humans should change the way they treat the earth as a whole.

7. Humans should focus on improving the quality of their life rather than on materialistic gains.

8. Those who subscribe to the foregoing points have an obligation, directly or indirectly, to try to implement the necessary changes by nonviolent means.

It, however, needs to be mentioned here that the above description of the Deep Ecology Movement and its platform principles is not an account of Naess's personal philosophy called Ecosophy Twhich is grounded in a special place called Tvergastein. In fact, Naess felt that people having faith in any kind of philosophy could have their own ecosophies. Hence, it is not surprising that these principles of Deep Ecology are supported by people from diverse backgrounds such as Buddhists, Taoists, Shamanists and ecofeminists et al who "could also have their own personal ecosophy" (Naess 2008, p. 30).

It may not be wrong to say that while ecocriticism explores the human-nature relationship in literature, Deep Ecology goes a step further by making a shift from 'anthropocentrism' to 'biocentrism' where nature and other life forms are considered as valuable as human beings. It proposes "a respect not only for all life forms but also towards landscapes such as rivers and mountains" (Nayar 2010, p. 247). This philosophical challenge to the 'anthropocentrism' of the West was posed by Rachel Carson's Silent Spring. In her book, Carson (1962) questions the indiscriminate use of pesticides which poses a threat to human life, but in reality "her concerns went deeper to encompass a respect and concern for the biological integrity of the Earth and all its species" (Sessions 1995, p. x). Silent Spring begins with the description of a prosperous town where all lived in harmony, but there is a sudden change in the fate of the town:

Some evil spell had settled on the community: mysterious maladies swept the flocks of chickens; the cattle and sheep sickened and died. Everywhere was a shadow of death. The farmers spoke of much illness among their families... There had been several sudden and unexplained deaths, not only among adults but even among children, who would be stricken suddenly while at play and die within a few hours. (Carson 1962, p. 1)

Carson asserts that this catastrophe was the outcome of human actions, implying that as long as humans continue to consider themselves the conquistadorsof earth, nature will continue to suffer (Singha 2019, p. 66). Hence, Deep Ecology views that all human and nonhuman life on earth including rivers, landscapes, and ecosystems, should flourish since "[t]rying to control the whole of nature is futile and wrong"(Naess 2008,p. 27). Noted historian and critic Ramchandra Guha (2004) opines that this ethic of Naess called biospheric egalitarianism“would be a truly 'deep' ecology, in contrast to the 'shallow' ecology which concerned itself merely with pollution or resource depletion without going to the deeper roots of the ecological crisis" (Guha 2004, p. 116). 
He writes on how during his years spent in the United States, he had come across a different kind of environmentalism which focusedtowards the rights of plants, animals, and wild habitats (ibid).

The ethic of biospheric egalitarianismcalls for a "deep-seated respect ... for ways and forms of life" (Naess 1005,p. 151-152). Interestingly, the Adi tribe of Arunachal Pradesh in Northeast India has been practicing this ethic since ages. The Adis believe in the philosophy of 'Donyi-Polo.' They recognize all things on earth such as "[the] mountains and hills, the evergreen forest, the rushing rivers and rivulets, the animals and birds, the moving cloud and rain-fall, the shining objects in the sky" (Ering 2004, p. 35) as sacred entities. The Donyi Polo Yekam Kebang (DYK)under the leadership of the late Talom Rukbo started the 'Donyi-Polo Movement' in 1968 as a protest against the "the policy of the Indian state and the interventions of Christian missionaries in the Adiinhabited areas" (Chaudhuri 2013,p. 261). It was felt that the advent of Christianity in the hills of Northeast India was taking a toll on the indigenous religions of the different tribal groups, and institutionalization is the only way to preserve such ancient faiths. The term 'Donyi-Polo' has been assigned three theological meanings: Donyi Polo is the God/Goddess; 'Donyi' is the Sun and 'Polo' is the Moon; finally, Donyi and Polo are two supreme bodies (Pangkam 2011).Doyni-Polo is also the "origin of all things, beings, spirits, time and forces" (Borang 2011, p. 39). Anthropologist Verrier Elwin considers Doyni-Polo as a supreme deity who "is as important to man as the eye is to the body" (Elwin 1999, p. 31). Thus, Donyi-Polo has been ascribed as the watcher, witness, guide, and protector of the Adis. TheDonyi-Polo worldview is also about maintaining an ecologically harmonious relationship among all creatures on earth. Poet and novelist Mamang Dai opines on what 'Donyi-Polo' means to the Adis:

The traditional belief of the Adi community to which I belong is full of this union [between man and nature]. Everything has life - rocks, stones, trees, rivers, hills, and all life is sacred. This is called Donyi-Polo, literally meaning Donyi- Sun, and Polo-moon as the physical manifestation of a supreme deity, or what I like to interpret as 'world spirit.'(Dai 2009, n.p)

Thus in the Adi worldview, the earth is a living being and all elements of nature are considered sacred and living.

Both 'Donyi-Poloism' and Deep Ecology are based on the biocentric assertion that all life forms are to be preserved and that humans are not the central figures to rule planet earth. The manifestation of this worldview is reflected in the poetry of Mamang Dai who has time and again writtenon the harmony between the human and the nonhuman world among the Adis, and the need to preserve this harmony in order to uphold the traditional faith of the tribe. It is in the light of the expression of this harmony found in Mamang Dai's work that this paper shall attempt a reading of select poems of Dai from her collection of poems titled Midsummer Survival Lyrics(2014), and explore the interconnections between the philosophies of Deep Ecology and Donyi-Polo, as reflected in her writings.

\section{Discussion:}

Mamang Dai is a noted poet, novelist and historian from Pasighat, a town in the East Siang district of Arunachal Pradesh. She is a former civil servant and journalist and has also worked with the World Wildlife Fund in Itanagar for the Eastern Himalaya Biodiversity Hotspots 
Program. In 2003, Dai received the prestigious 'Verrier Elwin Award' for her book Arunachal Pradesh - The Hidden Land. In 2011, Dai was honoured with the Padmashri. She has three poetry collections to her credit, River Poems (2004), The Balm of Time (2008) and Midsummer Survival Lyrics (2012). She has also authored non-fiction such as Arunachal Pradesh: The Hidden Land (2003/2009) and Mountain Harvest: The Food of Arunachal (2004). Her novels include The Legends of Pensam (2006), Stupid Cupid (2009) and The Black Hill (2014). Besides, her writings have appeared in numerous journals and anthologies across the world.

Mamang Dai belongs to the Adi community of Arunachal Pradesh whose faith is "woven around forest ecology and co-existence with the natural world" (Dai 2006, p. xi). Therefore, it is not surprising that her poetry should be inspired by the geography and landscape of Arunachal Pradesh. In her poetic world, nature is a living and breathing entity. The landscape of Arunachal Pradesh, its mountains, rain, forests, rivers et al are not just figments of imagination but do have a physical presence of their own, as evident when Dai says: "I live in a small town surrounded by hills. If I travel to other parts of the state it is the same - more mountains and forests, river crossings and rough roads. So the physical presence of the land is very tangible" (Subramaniam 2010, n.p.). It is perhaps from the sense of this 'tangible presence' of nature that the Adis have come to see every element of the earth as living and sacred. For instance, every little element of nature contributes to the flow of life on earth as Dai observes in the poem "Banjo Moon":

The tin roof is a music maker

drumming hard notes of water.

All night a pond

dreams of water lilies

to decorate its heart. (Dai 2014, p. 59)

The Adis claim to be the descendants of Abo Tani, the first man on earth who "was born out of the soil" (Pilliya 2006, p. 22). Since they revere nature, they "make it a point to take [from nature] only what is required” (Choudhury and Chakraborty 2017,p. 45). Mamang Dai's poetrycan be said to have been born out of such deep reverence and respect for the land she belongs to. That the land is a living entity and all forms of life inhabiting it are equal in stature, becomes explicit in the poem "Other Lives" where she describes the land as 'living and breathing.' Dai says that humans and nonhumans share the earth's resources and at times, also indulge in fights for survival, just like "two brothers claiming territory" (Basumatary 2016,p. 245). The struggle is real and unavoidable but not without a sense of mutual respect between the human and the nonhuman. The prose-poem reads thus:

The land is a being just like us. We live the weather, share food, rice, water, salt. We go to war, kill each other with our weapons and are killed by a drowning river or an avalanche of rocks. It is a bond both cruel and kind; like brothers claiming territory. Since both are equal to the other it is a state of mutual regard, a state of kinship. (Dai 2014,p. 44)

This sense of kinship and mutual regard between the human and the nonhuman perhaps comes from the NEFA (North-East Frontier Agency presently divided into Kameng, Subansiri, Siang, Lohit and Tirap divisions) traditions about the creation of the world wherein it is believed that "the earth and sky have descended from a sort of universal Mother" (Elwin 1999,p. 7) who was born out of the primeval fog and mist. Further, the Adis believed that from Keyum, the Great 
Mother "descended a line of mysterious beings down to Peddong-Nane, the living rock from whom Wiyus, men and animals were born" (ibid). All these beliefs establish the notion that all creations on earth owe their origin to a common mother figure. Hence, in the Adi worldview, there is no hierarchy of beings, and the human and the nonhuman such as bat, tiger, snake et al are siblings (Basumatary 2016, p. 243). This is in opposition to the Christian theological teachings which assert that "humans were assigned stewardship over every other creature in the world by God Himself" (ibid). Similarly, Lynn White (1996)had remarked that Western Christianity was the most anthropocentric religion of the world:

Man named all the animals, thus establishing his dominance over them. God planned all of this explicitly for man's benefit and rule... And although man's body is made of clay, he is not simply part of nature...

Christianity, in absolute contrast to ancient paganism and Asia's religions (except, perhaps, Zoroastrianism), not only established a dualism of man and nature but also insisted that it is God's will that man exploit nature for his proper ends. (White 1996, p. 9-10)

In contrast to the above, Mamang Dai writes on the human-tiger kinship and siblinghood in poems such as "Man and Brother" and "Man and Brother (2)." The footnote to the first poem reads: "It is a widespread belief in Arunachal Pradesh that man and tiger were born brothers. The killing of a tiger is equivalent to that of killing a man..." (Dai 2014, p. 49). In "Man and Brother" a hunter patiently awaits the arrival of a tiger in the forest. Suddenly he hears someone calling his name aloud. He realizes it was none other than his prey, the tiger:

The tiger runs swiftly from my father's house

Calling my name.

Brother: Man brother!

Have mercy for our destiny! (Dai 2014,p. 49)

When the tiger addresses the hunter as 'brother' and pleads mercy, the latter realizes that if he kills his own brother (the tiger), the entire village will have to observe rigorous penance for five days. So the hunter asks the tiger to run away from there: "Run swiftly then my brother / Oh, my brother, / have mercy for our destiny (ibid 50). Although it appears that the hunter does this to save the villagers from harsh punishment, but ultimately it is his self-realization of the value of other life forms which prevents him from killing his own sibling. This self-realization resonates in the poem "Man and Brother (2)." After the killing of the tiger by the human, when the latter realizes his act of wrongdoing, he cries out "seeking [his] brother's lost face" (Dai 2014, p. 51) since the tiger sacrificed himself in order to bring laurels of bravery and courage to his human brother: "Without his footprint, we would not know how to be brave" (ibid). According to a similar Mishmi(a tribal group of Arunachal Pradesh inhabiting the Lohit district) belief, a man and a tiger were born to the same mother and lived in the same house as siblings.This is why the Mishmi refrain from killing a tigerunless killed or trapped accidentally. The funeral of the tiger is carried out by a shaman, and the rituals continue for five days during which not only the person who killed the tiger but also the entire village has to observe strict taboos (Aiyadurai 2016, p. 305-315). 
The notion of ecological self is crucial to the understanding of Deep Ecology movement. Arne Naess asserts that traditionally the maturity of an individual is assessed in terms of his relationship to his family or society but

...in this conception of the maturity of the self, nature is largely left out. Our immediate environment, our home (where we belong as children), and the identification with nonhuman living beings are largely ignored. Therefore, I tentatively introduce, perhaps for the very first time, the concept of ecological self... Society and human relationships are important, but our own self is much richer in its constitutive relationships. These relationships are not only those we have with our humans and the human community...but also those we have with other living beings. (Naess 2008,p. 82)

Unless we learn to value our natural world, the maturity of the self remains incomplete. Man has to think of himself as a part of the natural world but not in any way superior to it. Thus, identification of one's ecological self is must in order preserve ecological harmony between the human and the nonhuman world. Similarly, the Donyi-Polo faith of the Adis is essentially an ideological pursuit based on nature which advocates for peaceful co-existence and absence of violence among all life forms on earth (Ering 2004, p. 35-37).

The identification of the 'ecological self' forms an essential theme in Midsummer Survival Lyrics. In the prose-poem titled "The deification of nature," Dai explicitly writes on the importance of the land, the mountains, trees and insects and the need to value their existence:

When we say our people believe that rocks and trees have life, what does it mean?

In this environment where we live and what we call our land, land of our ancestors, we cannot crush the mountains or tear off the green covering saying this is what is getting in the way of development. (Dai 2014, p. 53)

The Adis are people who believe that trees, rocks, rivers - everything has life. It is this faith that keeps the tribe in close harmony with nature, since the consciousness of the Adis is shaped by "the great forest, the mountains, the environment..." (Dai 2004,p. 92). Hence, any damage done to the natural world will have serious repercussions. But in the name of development, the modern man is moving away from his biocentric ethic. He is causing harm to the planet, by crushing the mountains and felling the forests. But ironically, humans have always put the blameon the nonhuman world for such disruption of earth's equilibrium. This is because humans have always believed that every other thing on earth exists to provide comfort to them (human beings). In the poem "The face of the tiger" Dai writes on how humans have never accepted the fact that they have been exploiting the earth's resources for their own interests. In this poem, a group of men preparing for a tiger-hunt unanimously opine that the tiger is destroying their crops, killing animals and encroaching their land. Ironically, they never admit that it is they who are plundering the forest wealth forcing the tiger to come out of its habitat:

"Why are they moving into the territories of men? / ... / We only know that the tiger is straying into cultivation fields and attacking precious livestock" (Dai 2014, p. 48). 
The poem "Be careful how you cut that tree" is a prophetic warning to humans to refrain themselves from causing damage to nature. Dai refers totrees as 'priests' and 'gods of a pre-human age' who keep a watch on human actions on earth. The felling of a tree can have serious repercussions in the human world and man might not be able to recuperate from the aftermath. Dai writes:

Be careful how you cut that tree.

A dizzy blow can change the sunlight, Alter the snaking path of a breeze;

Kill the ground with unexpected poison - heat

these things are unpredictable. (Dai 2014, p. 64)

Such prophetic warnings of human actions causing harm to nature and its consequent repercussion can be found in Dai's fiction too. For example, in The Legends of Pensam, the felling of trees disturbs the ancestral spirits of the tribe and the entire community has to face the aftermath:

But the big trees were brought down. The spirits of our ancestors who dwelt in these high and secret places fell with the tress. They were homeless, and so they went away. And everything had changed since then. The canopy of shelter and tradition had fallen. The wind and the sun burned our faces. We saw a strange new glimmer in the distance. Our footsteps led us down unknown paths. (Dai 2006, p. 42-43)

The poem "Midday sun" is yet another example of this unending strife between the human and the nonhuman world where the former is always intervening and trying to take control of the latter. In the poem, a rhinoceros strives hard to find a resting place but there is none since everything is occupied by the humans: "Where is that uninterrupted place / of rivers and wet grass?" (Dai 2014, p. 67). The poet remembers creatures such as the squirrel and the iguana but now all these are "lost, petrified, drowned" (ibid). The poet raises a pertinent question: "What will happen at the end of the struggle?" only to come up with an answer such as: "Perhaps the silence of the earth will deepen" (ibid).

In the poem "Tug of war" Dai once again declares that human beings can never be superior to nature. She asserts that in the tug of war between human and nature, the former shall always succumb to the will of latter. In this poem, a group of men injure a python in the woods and later decide to carry it to their village as a mark of victory. The snake appears to be dead. But nature restores all its strength, and it escapes the clutches of the self-acclaimed conquistadors. Dai gives a powerful and vivid description of the episode that acts as a reminder to all humans on earth to value other life forms:

Suddenly the inert snake rippled through their clenched arms and slipped out of their embrace. The scent of water, the sound of the stream had given the poor, bruised python a burst of strength ... Not a man was left standing. The snake had simply flexed its muscles, instinct showed it the way and, they said, the men were left gasping, fallen on the ground, simply flung aside, as if the snake had shed its skin.(Dai 2014, p. 69) 
In her poetry, Mamang Dai often writes about her belief in the elemental forces of nature, in the power of the river, mountains and the rain. Rivers are beautiful yet fearsome. She writes: "Rivers can do anything, / capsize boats / plunge into the earth" (Dai 2014, p. 71). The fury of the rivers can be dangerous for they swallow "houses, statues, temples, pilgrims" (Dai 2014, p. 10). Since Dai grew up in the snowcapped mountains of Arunachal Pradesh, hence her reverence for the mountain is not surprising. The mountain is a living memory for her. Although the origin of the Adis is shrouded in mystery and nothing is certain about the past of the tribe, the mountains have always been there, acting as sentinels and guardians of the Adis since ages: "There are mountains. Oh! There are mountains. / We climbed every slope" (Dai 2014, p. 18). Dai's reverence and admiration for mountains is similar to Arne Naess's perception of mountains: "From the mountains, we learn modesty; their size makes us feel small and humble, and so we participate in their greatness" (Naess 2008, p. 17). In the poem titled "Writing" Dai considers herself and the entire human race as small silhouettes compared to the mighty mountain: "We are small solitary silhouettes trying to embrace the mountain. The impression of a fern is stronger than us" (Dai 2014, p.2). The concluding line of the poem once again reiterates the need to move away from anthropocentric ways of life towards developing an ecosophy of living harmoniously with and in nature.

\section{Conclusion}

This paper aimed to bring out how the philosophy of Donyi-Polo practiced by the Adi tribe of Arunachal Pradesh in India's Northeast coincides with the platform principles of the Deep EcologyMovement pioneered by the Norwegian philosopher Arne Naess. The Adis consider everything on the earth to be sacred, which goes in sync with Naess's philosophy of Deep Ecology that sees the intrinsic worth of all creatures on earth.

\section{References}

Agarwal, Nilanshu Kumar. (2009). Interview with Mamang Dai. Subtle Tea Productions. Retrieved 10 June 2016, fromhttp://www.subtletea.com/mamangdaiinterview.htm

Aiyadurai, A. (2016). 'Tigers are Our Brothers': Understanding Human-Nature Relations in the Mishmi Hills, Northeast India. Conservation and Society. Vol. 14, No.4, pp. 305-316. Retrieved 25 April, 2019, from

http://www.conservationandsociety.org/article.asp?issn=09724923;year=2016; volume=14;issue=4;sp age $=305$; page $=316$; aulast $=$ Aiyadurai

Basumatary, F. (2016). Traditional World-view of the Adi Tribes of Arunachal Pradesh and the Poetry of

Mamang Dai: a Parellel Reading. In Z. Khaingte. (Ed), Orality: The Quest for Meanings (pp. 240249). Partridge India.

Borang, K. (2004). Philosophy of Donyi Polo. In T. Mibang and S. K. Chaudhuri (Eds.), Understanding

Tribal Religion (pp. 39-45). New Delhi, India: Mittal Publications.

---. (Ed.). (2011). Socio Cultural and Spiritual Traditions of Arunachal Pradesh. Guwahati: Heritage

Foundation. 
Carson, R. (2006).Silent Spring. PDF file.

Chaudhuri, Sarit Kumar. (2013). The Institutionalization of Tribal Religion: Recasting the Donyi-Polo Movement in Arunachal Pradesh. Asian Ethnology. Vol. 72, no. 2. pp. 259-277. Retrieved 15 April 2016, from https://asianethnology.org/downloads/ae/pdf/AE\%20722\%20AE\%20\%20Chaudhuri.pdf

Choudhury, A. S., \& Chakraborty C. (2017). The Representation of the Ethnic Life-World of the Adis in Mamang Dai's The Legends of Pensam: An Ecocritical Reading. InLapis Lazuli: An International Literary Journal, 7 (2), p. 42-53. Retrieved 19 July, 2020, from https://www.academia.edu/36807920/The_Representation_of_the_Ethnic_Life_World_of_the_Adis _in_Mamang_Dais_The_Legends_of_Pensem_An_Ecocritical_Reading

Dai, Mamang. (2004). The Nature of faith and Worship Among the Adis. In T. Mibang and S. K. Chaudhuri (Eds.), Understanding Tribal Religion (pp. 87-94). New Delhi, India: Mittal Publications.

---. (2006). The Legends of Pensam. New Delhi, India: Penguin Random House.

---. (2014). Midsummer Survival Lyrics. Guwahati, India: Wordsmith.

---. (2014). Banjo Moon. In Midsummer Survival Lyrics, p. 59.

---. (2014). Other lives. In Midsummer Survival Lyrics, p. 44.

---. (2014).Man and brother. In Midsummer Survival Lyrics, p. 49-50.

---. (2014).Man and brother (2). In Midsummer Survival Lyrics, p. 51-52.

---. (2014).The deification of nature. In Midsummer Survival Lyrics, p. 53.

---. (2014).The face of the tiger. In Midsummer Survival Lyrics, p. 48.

---. (2014). Be careful how you cut that tree. In Midsummer Survival Lyrics, p. 64.

---. (2014).Midday sun. In Midsummer Survival Lyrics, p. 67-68.

---. (2014).Rivers. In Midsummer Survival Lyrics, p. 71-72.

---. (2014).Midsummer. In Midsummer Survival Lyrics, p. 10.

---. (2014).An obscure place. In Midsummer Survival Lyrics, p. 18-19.

---. (2014).Writing. In Midsummer Survival Lyrics, p. 2.

Elwin, V. (1999). Myths of the Northeast Frontier of India. New Delhi: Munshiram Manoharlal Publishers.

Ering, Oshong. (2004). Philosophy of Donyi Polo. In T. Mibang and S. K. Chaudhuri (Eds.), Understanding Tribal Religion (p. 35-37). New Delhi: India, Mittal Publications.

Glotfelty, C \&Fromm H. (1996). The Ecocriticism Reader: Landmarks in Literary Ecology. London: The University of Georgia Press.

Guha, Ramchandra. (2004). Environmentalism: A Global History. New Delhi, India: Penguin Random House India.

Mibang, T., \& Chauudhuri S.K. (2004). Understanding Tribal Religion. New Delhi, India: Mittal Publications. 
Naess, Arne. (1995). The Shallow and the Deep, Long-Range Ecology Movements: A Summary. In G. Sessions (Ed.), Deep Ecology for the Twenty-First Century. London: Shambhala Publications.

---. (2008). Ecology of Wisdom. Drengson A, \&Devall B (Eds.), Penguin.

Nayar, Pramod. K. (2010). Contemporary Literary and Cultural Theory: From Structuralism to Ecocriticism. New Delhi: Pearson India.

Pangkam, Tasik. (2011). Culture and Spiritual Philosophy of the ADIS of Upper Siang. In Kaling Borang (Ed.), Socio Cultural and Spiritual Traditions of Arunachal Pradesh (p. 52-62), Heritage Foundation.

Pilliya, H. (2006). The Legend of Abo-Tani: the first man on earth: ARUNACHAL. In G. Sen (Ed.), Where the Sun Rises When the Shadows Fall: The Northeast (p. 22-25), OUP.

Sen, Geeti. (Ed.). (2006). Where the Sun Rises When the Shadows Fall: The Northeast. Oxford University Press.

Sessions, George. (Ed.). (1995). Deep Ecology for the Twenty-First Century. London: Shambhala Publications.

Singha, Sukla. (2019). Analyzing and situating English poetry of the North-East towards the formulation of an alternative canon: Problems and issues with reference to select poets and texts (Unpublished doctoral dissertation). Tripura Central University, Tripura, India.

Subramaniam, A. (2010). Interview with Mamang Dai, The Land as "Living Presence."Poetry International. Retrieved 10 June 2014, from https://www.poetryinternational.org/pi/cou_article/17068/The-Land-as-Living-Presence White, L. (1996). The Historical Roots of Our Ecologic Crisis. In C. Glotfelty \& H. Fromm (Eds.), The Ecocriticism Reader: Landmarks in Literary Ecology (p. 3-14). London: The University of Georgia Press.

Sukla Singha is a Research Scholar in the Department of English, Tripura University. She has defended her PhD thesis and is awaiting for certification. 